Ege Tıp Dergisi / Ege Journal of Medicine 2019; 58 (3): 295-302

\title{
Aspirinin insan kaynaklı hepatoma hücrelerinde paraoksonaz enzimlerinin protein düzeylerine ve arilesteraz aktivitesine etkisi
}

\author{
Effect of aspirin on protein levels of paraoxonase enzymes and arylesterase \\ activity in human-derived hepatoma cells
}

\author{
Eray Özgün Gülben Sayılan Özgün (D)
}

Trakya Üniversitesi Tıp Fakültesi, Tıbbi Biyokimya Anabilim Dalı, Edirne, Türkiye

\section{Öz}

Amaç: $\mathrm{Bu}$ çalışmanın amacı, aspirinin insan kaynaklı hepatoma hücrelerinde paraoksonaz-1, paraoksonaz-2 ve paraoksonaz-3 protein düzeylerine ve arilesteraz aktivitesine etkisini araştırmaktır.

Gereç ve Yöntem: HepG2 hücreleri kontrol, $0.25 \mathrm{mM}$ aspirin, $0.5 \mathrm{mM}$ aspirin ve $1 \mathrm{mM}$ aspirin olmak üzere 4 gruba ayrıldı ve hücreler 48 saat boyunca sırasıyla $0,0.25,0.5$ ve $1 \mathrm{mM}$ aspirin ile inkübe edildi. Hücre canlılığı 3-(4,5-Dimetil-2-tiazolil)-2,5-difenil-2H-tetrazolium bromür testi ile ölçüldü. Paraoksonaz-1, paraoksonaz-2 ve paraoksonaz-3 protein düzeyleri western blot yöntemiyle ölçüldü. Arilesteraz aktivitesi substrat olarak fenilasetat kullanılarak spektrofotometrik olarak ölçüldü.

Bulgular: $0.5 \mathrm{mM}$ ve $1 \mathrm{mM}$ aspirin hücre canlıığında anlamlı azalmaya yol açtı. Aspirin konsantrasyonları paraoksonaz-1 ve paraoksonaz-2 protein düzeylerini anlamlı olarak değiştirmedi. 0.5 ve $1 \mathrm{mM}$ aspirin paraoksonaz-3 protein düzeylerini anlamlı olarak arttırdı. $0.25 \mathrm{mM}, 0.5 \mathrm{mM}$ ve $1 \mathrm{mM}$ aspirin, arilesteraz aktivitesini anlamlı olarak artırdı.

Sonuç: Çalışmamız aspirinin insan kaynaklı hepatoma hücrelerinde paraoksonaz-1 ve paraoksonaz-2 protein düzeylerini değiştirmediğini, paraoksonaz-3 protein düzeylerini ve arilesteraz aktivitesini arttırdığını gösterdi.

Anahtar Sözcükler: Aspirin, paraoksonaz-1, paraoksonaz-2, paraoksonaz-3, arilesteraz.

\begin{abstract}
Aim: The aim of this study is to investigate the effect of aspirin on paraoxonase-1, paraoxonase-2 and paraoxonase-3 protein levels and arylesterase activity in human-derived hepatoma cells.

Materials and Methods: HepG2 cells were divided into four groups: control, $0.25 \mathrm{mM}$ aspirin, $0.5 \mathrm{mM}$ aspirin and $1 \mathrm{mM}$ aspirin and cells were incubated with 0, 0.25, 0.5 and $1 \mathrm{mM}$ aspirin, respectively. Cell viability was evaluated by 3-(4,5-dimethyl-2-thiazolyl)-2,5-diphenyl-2H-tetrazolium bromide assay. Paraoxonase-1, paraoxonase-2 and paraoxonase-3 protein levels were measured by western blotting. Arylesterase activity was measured spectrophotometrically by using phenylacetate as substrate.

Results: $0.5 \mathrm{mM}$ and $1 \mathrm{mM}$ aspirin caused a significant decrease on cell viability. Aspirin concentrations did not significantly change paraoxonase-1 and paraoxonase-2 protein levels. $0.5 \mathrm{mM}$ and $1 \mathrm{mM}$ aspirin significantly increased paraoxonase-3 protein levels. $0.25 \mathrm{mM}, 0.5 \mathrm{mM}$ and $1 \mathrm{mM}$ aspirin significantly increased arylesterase activity.

Conclusion: Our study showed that aspirin does not change paraoxonase-1 and paraoxonase-2 protein levels but increases paraoxonase-3 protein levels and arylesterase activity in human-derived hepatoma cells.
\end{abstract}

Keywords: Aspirin, paraoxonase-1, paraoxonase-2, paraoxonase-3, arylesterase.

\footnotetext{
Yazışma Adresi: Eray Özgün

Trakya Üniversitesi Tıp Fakültesi, Tıbbi Biyokimya Anabilim

Dalı, Edirne, Türkiye

E-mail:drozgune@hotmail.com

Makalenin Geliş Tarihi: 11.10.2018

Kabul Tarihi: 29.11.2018
} 


\section{Giriş}

Aspirin -asetilsalisilik asit- bir asırdan daha uzun zamandır kullanılmakta olan ve günümüzde en çok kullanılan ilaçlardan biridir. Yapısında asetil grubu ve salisilat metaboliti olmak üzere iki aktif molekül içeren aspirinin esas olarak ağrı kesici ve antiinflamatuvar özellikleri iyi bilinmektedir (1). Aspirin, trombositlerde siklooksijenazları asetilleyerek antitrombotik etki göstermesi sebebiyle, günümüzde kardivasküler hastalıkların önlenmesinde ve tedavisinde de kullanılmaktadır (2).

Paraoksonaz enzim ailesi paraoksonaz (PON)1, PON2, PON3 olmak üzere üç üyeden oluşmaktadır. PON1 ve PON3 enzimleri esas olarak karaciğerde sentezlenmekte ve dolaşımda yüksek dansiteli lipoprotein (HDL)'ye bağlı olarak taşınmaktadır. PON2 enzimi ise neredeyse tüm dokularda sentezlenebilen hücre içi bir enzimidir (3). PON enzimlerinin hepsi antioksidan özelliklere sahiptir ve ateroskleroza ve koroner kalp hastalıklarına karşı koruyucu etkileri bulunmaktadır (4). Aynı enzim ailesinden olmalarına rağmen PON enzimlerinin düzenlenmesi bakımından farklılıklar bulunmaktadır (5), biz de önceki çalışmalarımızda PON1 ve PON3 gen ekspresyonlarının ve protein düzeylerinin farklı moleküller tarafından farklı şekillerde düzenlendiğini göstermiştik $(6,7)$. Literatürde genellikle PON1 enzimi üzerine yapılmış çalışmalar bulunmakla birlikte PON2 ve PON3 ile ilgili olarak ise çok daha az sayıda çalışma vardır ve bu sebeple yeni çalışmalara intiyaç bulunmaktadır (3-5).

PON enzimleri farklı substratlara karşı farklı aktiviteler gösterebilmektedir. Enzim ailesine adını veren paraoksonun hidrolizi ile karakterize PON aktivitesine sadece PON1 enzimi sahipken PON2 ve PON3 enzimi PON aktivitesi göstermez. Fenilasetatın hidrolizi ile karakterize arilesteraz aktivitesi de en sık bilinen ve ölçülen PON enzimlerine ait aktivitelerdendir. Arilesteraz aktivitesi esas olarak PON1 enzimine ait olmakla birlikte PON3 enzimi az, PON2 enzimi ise daha da az miktarda arilesteraz aktivitesi göstermektedir (8). Özellikle arilesteraz aktivitesi çok düşük enzim konsantrasyonlarında bile ölçülebilmesi sebebiyle özellikle hücre kültürü çalışmalarında ölçümü sıklıkla yapılan enzim aktivitesidir (6,9). PON1 enzimi aynı zamanda esteraz aktivitesi göstermekte olup aspirinin de PON1 enzimi için bir substrat olduğu ve plazmada PON1 enzimi tarafından hidroliz edildiği gösterilmiştir $(10,11)$.

HepG2 hücreleri ticari olarak satılan insan kaynaklı karaciğer hepatoma hücreleridir ve hepatositlere birçok biyolojik özellikleri benzedikleri için, bu hücreler karaciğer protein sentezinin araştırılması için uygun hücrelerdir (12). Literatürde karaciğerde aspirinin PON1 enzimi üzerine etkisinin araştırılmasında da HepG2 hücreleri kullanılmıştır (9).

Aspirinin insan çalışmalarında serum PON1 düzeylerine ve aktivitesine (13), in vitro olarak karaciğer kaynaklı hücrelerde ise PON1 mRNA ekspresyonlarına ve arilesteraz aktivitesine (9) etkileri gösterilmiş olmasına rağmen literatürde aspirinin karaciğerde PON1 protein düzeylerine etkisini araştıran bir çalışmaya rastlamadık. Aynı zamanda literatürde aspirinin PON2 ve PON3 enzimleri üzerine etkisini araştıran bir çalışma da bulunmamaktadır.

$\mathrm{Bu}$ çalışmanın amacı, aspirinin insan kaynaklı hepatoma hücrelerinde PON1, PON2 ve PON3 protein düzeylerine ve arilesteraz aktivitesine etkisinin araştııılmasıdır. Bu amaçla HepG2 hücrelerine farklı konsantrasyonlarda aspirin uygulanarak, aspirinin hücre canlılığına, PON1, PON2 ve PON3 protein düzeylerine ve arilesteraz aktivitesine etkisi araştırılmıştır.

\section{Gereç ve Yöntem}

Kimyasallar

HepG2 hücreleri, American Type Culture Collection'dan (Middlesex, İngiltere) temin edildi. Çalışmada kullanılan EMEM Wisent (Quebec, Kanada); Fetal Bovine Serum (FBS) ve kemilüminesans (ECL) substrat Thermo Fisher (Waltham, MA, ABD); aspirin, dimetil sülfoksit (DMSO), 3-(4,5-Dimetil-2-tiazolil)-2,5-difenil-2Htetrazolium bromür (MTT) ve fenilasetat SigmaAldrich Co. (St. Louis, MO, ABD); polivinilidin florür (PVDF) membrane Bio-Rad (Hercules, CA, ABD); Radioimmünopresipitasyon (RIPA) lizis tamponu ve PON1 primer antikoru Santa Cruz (Heidelberg, Almanya); PON2, PON3 ve tübülin primer antikorları ve sekonder antikorlar Abcam (Cambridge, İngiltere) markaydı. Diğer tüm kimyasallar Sigma-Aldrich Co. (St. Louis, MO, $A B D$ ) veya Merck (Darmstadt, Almanya) markaydı. Tüm kimyasallar analitik saflıktaydı. 
Hücre kültürü ve aspirin uygulaması

Deneylerde 11. ile 16. pasajlar arasındaki hücreler kullanıldı. Hücreler $\% 10$ FBS içeren EMEM mediumu ile $\% 5 \quad \mathrm{CO}_{2}{ }^{\prime} l \mathrm{li}$ ortamda $37^{\circ} \mathrm{C}$ 'de inkübatörde yaşatıldı. Hücreler tüm deneylerde kontrol $(0 \mathrm{mM}), 0.25 \mathrm{mM}$ aspirin, $0.5 \mathrm{mM}$ aspirin ve $1 \mathrm{mM}$ aspirin olmak üzere 4 gruba ayrılarak, gruplar 48 saat boyunca sırasiyla $0,0.25,0.5$ ve 1 $\mathrm{mM}$ aspirin ile inkübe edildi. Aspirin, DMSO'da çözüldü, ve tüm hücrelere uygulanan toplam DMSO konsantrasyonu \%0.2'idi. Aspirin konsantrasyonları; literatürde HepG2 hücrelerinde aspirinin PON1 gen ekspresyonu üzerine etkisini araştıran Jaichander ve ark. (9) çalışmasından seçildi ve aspirinin genellikle kullanılan in vivo tedavi düzeyleri (14) ile uyumluydu.

\section{MTT hücre canlılığı testi}

3-(4,5-Dimetil-2-tiazolil)-2,5-difenil-2H-tetrazolium bromür (MTT) testi ile değerlendirildi. 96 kuyucuklu plakaya $10^{4}$ hücre ekildi ve 24 saat sonra deneysel prosedür gerçekleştirildi. Medium alınarak yerine PBS'de çözünen $10 \mu \mathrm{l}$ MTT $(5 \mathrm{mg} / \mathrm{ml})$ ve $100 \mu \mathrm{l}$ fenol red içermeyen medium eklendi. 4 saat $37^{\circ} \mathrm{C}$ 'de karbondioksitli inkübatörde inkübe edilen hücrelerden MTT içeren medium alınarak yerine $200 \mu \mathrm{l}$ DMSO ve $25 \mu \mathrm{l}$ Sorenson tamponu $(0.1 \mathrm{M}$ glisin, $0.1 \mathrm{M}$ sodyum klorür, $0.1 \mathrm{M} \mathrm{NaOH}$ ile $\mathrm{pH}$ : 10.5 ayarlanır) eklendi. Oluşan renk 570/630 nm'de mikroplaka okuyucuda ölçüldü (15). Sonuçlar, kontrol grubunun ortalamasına oranlanarak kontrol grubuna göre \% şeklinde verildi.

\section{Western Blot ile protein düzeyi ölçümü}

Deneysel prosedür sonrası hücre RIPA lizis tamponu ile homojenize edildi. Homojenatlar $15,000 \times$ g'de $+4^{\circ} \mathrm{C}$ 'de 10 dakika santrifüj edilerek, supernatantlar ayrıldı ve Lowry metoduna (16) göre total protein düzeyleri ölçüldü. PON1 ve PON3 için $50 \mu \mathrm{g}$, PON2 için ise $25 \mu \mathrm{g}$ total protein SDS-poliakrilamid jel elektroforezi ile ayrıştırılarak yarı ıslak sistem ile PVDF membrana aktarıldı. Bir saat $\% 5$ süt tozu ile bloklanan membranlar, gece boyu primer antikorlar (PON1 1:100, PON3 1:1000, PON2: 1:10000 ve tübülin 1:10000) ile inkübe edilerek, 1 saat sekonder antikorlar (anti-mouse ya da anti-rabbit; 1:20000 dilüsyon) ile inkübe edildi. Proteinler bandlarının görüntüsü $\mathrm{ECL}$ substrat kullanılarak alındı. Image J programı kullanılarak protein bandı yoğunlukları hesaplandı (17); PON1, PON2 ve PON3 düzeyleri yükleme kontrolü olarak kullanılan tübüline oranlandı ve her bir aspirin konsantrasyonu aynı deneysel prosedürdeki kontrol değerine oranlanarak kontrolün katı olarak verildi.

\section{Arilesteraz aktivitesi ölçümü}

Deneysel prosedür sonrası hücreler yıkanarak, 1 $\mathrm{mM}$ fenil asetat, $1 \mathrm{mM} \mathrm{CaCl}$ içeren $50 \mathrm{mM}$ Tris$\mathrm{HCl} \mathrm{pH:8} \mathrm{tamponu} \mathrm{ile} 10$ dakika $37^{\circ} \mathrm{C}$ 'de inkübe edildi ve oluşan ürün miktarı 270 nm'de ölçülerek, reaktif körüne göre absorbans artışı hesaplandı (18). Protein ölçümü için hücrelere $0.5 \mathrm{M} \mathrm{NaOH}$ eklendi ve total protein düzeyleri Lowry metoduna (16) göre ölçüldü ve sonuçlar protein düzeyine oranlandı. Sonuçlar, kontrol grubunun ortalamasına oranlanarak kontrolün katı olarak verildi.

\section{Istatistiksel analiz}

İstatistiksel analizler SPSS 20.0 (IBM SPSS Inc., Chicago, IL, ABD) programı kullanılarak Tek Yönlü Varyans Analizi ve gruplar arası karşılaştırmalar Tukey ve Tamhane testleri ile yapıldı. Sonuçlar ortalama \pm standart sapma olarak verildi ve $p<0.05$ istatistiksel olarak anlamlı kabul edildi.

\section{Bulgular}

Kontrol grubuna göre ortalama hücre canlılığı yüzdesi, $0.25 \mathrm{mM}$ aspirin uygulanan hücrelerde $\% 97 \pm 5, \quad 0.5 \mathrm{mM}$ aspirin uygulanan hücrelerde $\% 85 \pm 4$ ve $1 \mathrm{mM}$ aspirin uygulanan hücrelerde $\% 63 \pm 7$ idi (Şekil-1). $0.5 \mathrm{mM}$ ve $1 \mathrm{mM}$ aspirin hücre canlılığını, kontrole ve $0.25 \mathrm{mM}$ aspirine göre anlamlı olarak azalttı (tümü için $p<0.05$ ). $1 \mathrm{mM}$ aspirin hücre canlılığını, $0.5 \mathrm{mM}$ aspirine göre anlamlı olarak azalttı $(p<0.05)$.

$0.25,0.5$ ve $1 \mathrm{mM}$ aspirin uygulan hücrelerin PON1 protein düzeyleri sırasıyla kontrol grubunun $1.07 \pm 0.13,1.12 \pm 0.14$ ve $1.14 \pm 0.29$ katı idi (Şekil2). PON1 protein düzeyleri bakımından gruplar arasında istatistiksel olarak anlamlı fark yoktu $(p>0.05)$.

$0.25,0.5$ ve $1 \mathrm{mM}$ aspirin uygulan hücrelerin PON2 protein düzeyleri sırasıyla kontrol grubunun $1.05 \pm 0.11,1.06 \pm 0.14$ ve $1.07 \pm 0.14$ katı idi (Şekil2). PON2 protein düzeyleri bakımından gruplar arasında istatistiksel olarak anlamlı fark yoktu $(p>0.05)$. 


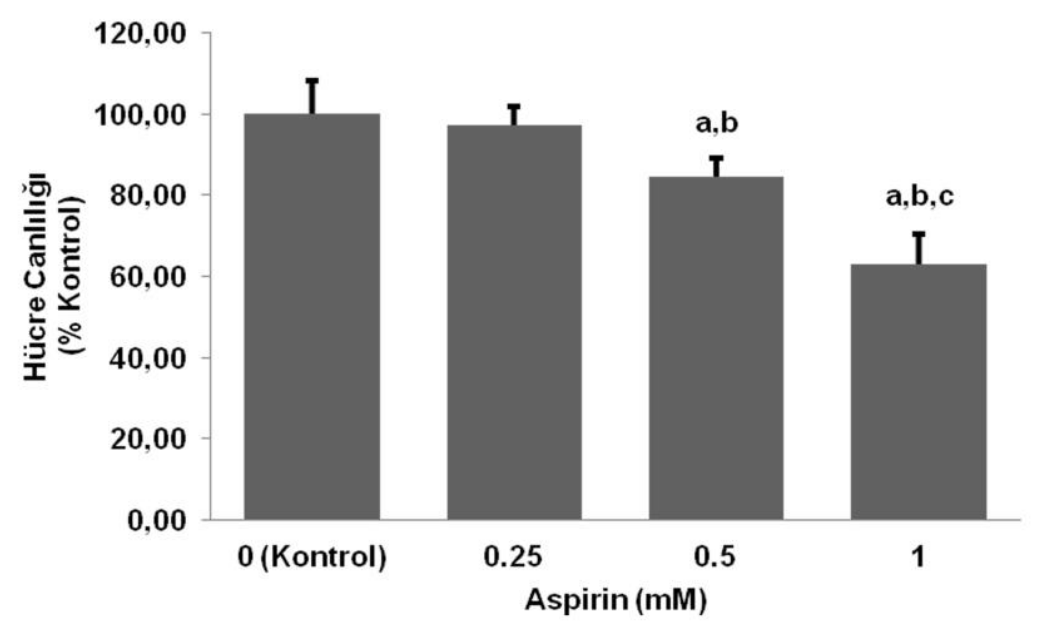

Şekil-1. HepG2 hücrelerine 48 saat süreyle uygulanan aspirinin hücre canlılığına etkisi.

Sonuçlar ortalama \pm standart sapma olarak verildi (tüm gruplar için $n=16$ ). İstatistiksel analiz Tek Yönlü Varyans Analizi ve gruplar arası karşılaştırmalar Tamhane testi ile yapıldı.

a: Kontrol grubu ile karşıllaştıııldığında $p<0.05$.

b: $0.25 \mathrm{mM}$ aspirin ile karşılaştıııldığında $p<0.05$.

c: $0.5 \mathrm{mM}$ aspirin ile karşılaştırıldığında $p<0.05$.

A)
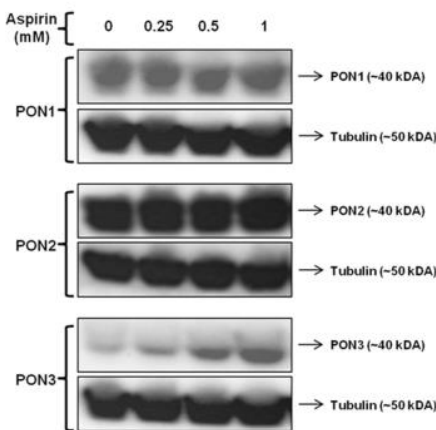

C)

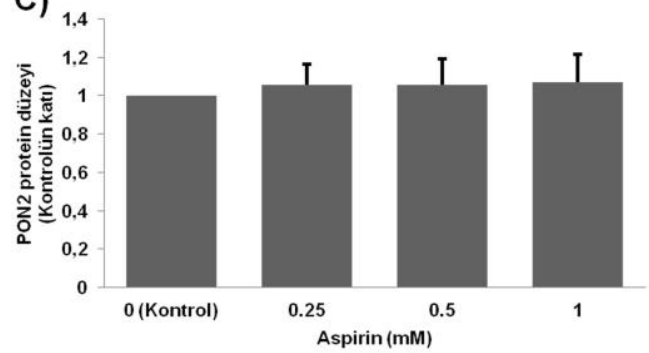

B)

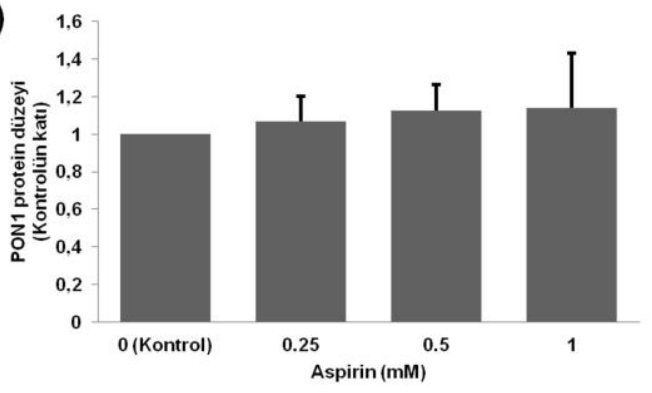

D)

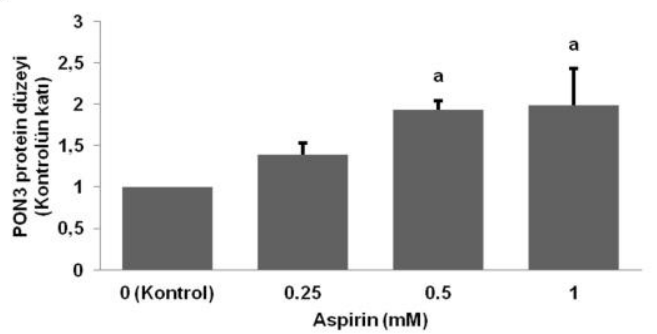

Şekil-2. HepG2 hücrelerine 48 saat süreyle uygulanan aspirinin paraoksonaz enzim düzeylerine etkisi.

A) Grupların paraoksonaz düzeylerine ait ve her bir paraoksonaz proteini için yükleme kontrolü olarak kullanılan tübüline ait western blot görüntüleri ve gruplara ait B) paraoksonaz 1, C) paraoksonaz-2 ve D) paraoksonaz-3 protein düzeyleri. Üç bağımsız deneysel prosedürün sonuçları ortalama \pm standart sapma olarak verildi (tüm gruplar için n=3). İstatistiksel analiz Tek Yönlü Varyans Analizi ve gruplar arası karşılaştırmalar Tukey testi ile yapıldı.

a: Kontrol grubu ile karşılaştııılı̆ğında $p<0.05$. 


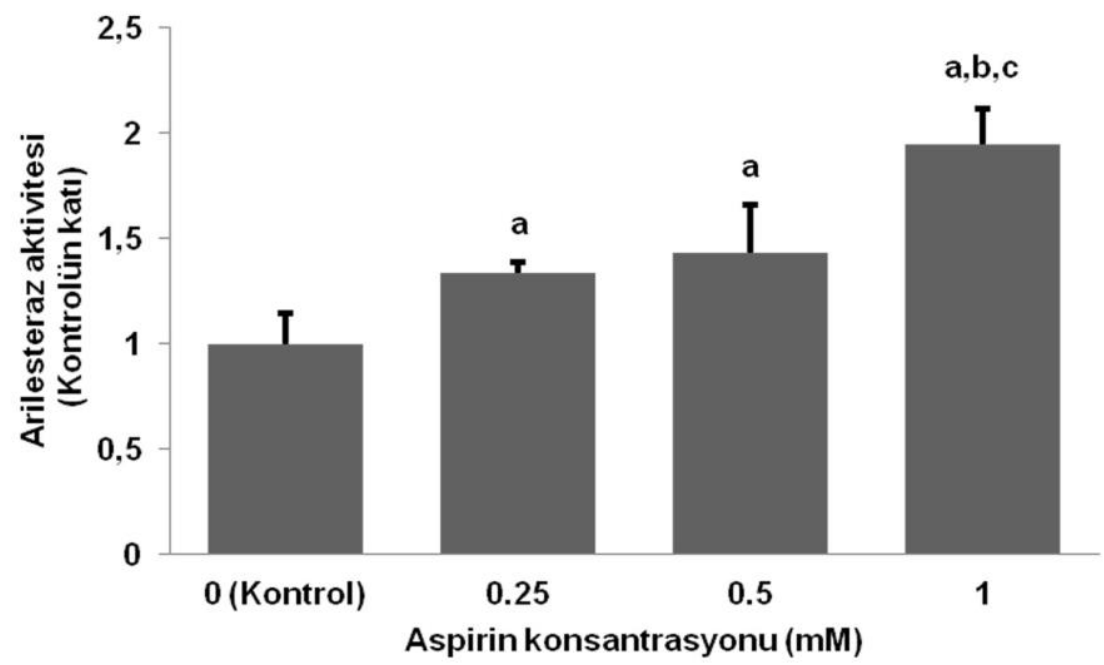

Şekil-3. HepG2 hücrelerine 48 saat süreyle uygulanan aspirinin arilesteraz aktivitesine etkisi.

Sonuçlar ortalama \pm standart sapma olarak verildi (tüm gruplar için $n=4$ ). İstatistiksel analiz Tek Yönlü Varyans Analizi ve gruplar arası karşılaştırmalar Tukey testi ile yapıldı.

a: Kontrol grubu ile karşıllaştıııldığında $p<0.05$.

b: $0.25 \mathrm{mM}$ aspirin ile karşıllaştırıldığında $p<0.05$.

c: $0.5 \mathrm{mM}$ aspirin ile karşılaştırıldığında $p<0.05$.

$0.25,0.5$ ve $1 \mathrm{mM}$ aspirin uygulan hücrelerin PON3 protein düzeyleri sırasıyla kontrol grubunun $1.39 \pm 0.14,1.93 \pm 0.11$ ve $1.99 \pm 0.44$ katıydı (Şekil2). $0.5 \mathrm{mM}$ ve $1 \mathrm{mM}$ aspirin uygulanan hücrelerde PON3 protein düzeyleri kontrol grubuna göre anlamlı olarak yüksekti (her ikisi için, $p<0.05$ ).

$0.25,0.5$ ve $1 \mathrm{mM}$ aspirin uygulan hücrelerin arilesteraz aktiviteleri sırasıyla kontrol grubunun $1.34 \pm 0.05,1.43 \pm 0.23$ ve $1.95 \pm 0.17$ katıydı (Şekil3). $0.25 \mathrm{mM}, 0.5 \mathrm{mM}$ ve $1 \mathrm{mM}$ aspirin uygulanan hücrelerde arilesteraz aktiviteleri kontrol grubuna göre anlamlı olarak yüksekti (tümü için, $p<0.05$ ). 1 $\mathrm{mM}$ aspirin uygulanan hücrelerde arilesteraz aktivitesi $0.25 \mathrm{mM}$ ve $0.5 \mathrm{mM}$ aspirin uygulanan hücrelere göre anlamlı olarak yüksekti (her ikisi için, $p<0.05)$.

\section{Tartışma}

Aspirin bilinen en eski ilaçlardan olmasına rağmen halen farkı endikasyonlarla kullanımı devam etmekte olan ve sürekli yeni çalışmalarla etkileri araştırılmakta olan bir moleküldür. Kardivasküler hastalıkların önlenmesi ve tedavisi aspirinin en önemli kullanım endikasyonlarından birisi $(1,2)$ olmasına rağmen vücutta ateroskleroz ve koroner kalp hastalığı gelişimine karşı mücadele eden antioksidan PON enzimleri üzerine etkisi tam olarak aydınlatılabilmiş değildir.

$\mathrm{Bu}$ sebeple çalışmamızda aspirinin PON enzimlerinin esas sentez yeri olan karaciğerde PON proteinlerinin düzeylerine ve arilesteraz aktivitesine etkisini araştırmayı amaçladık. Bu çalışma ile aspirinin PON2 ve PON3 enzimlerine ve karaciğerde PON1 protein düzeylerine etkisi ilk kez araştırıldı.

$\mathrm{Bu}$ çalışmada literatürde aspirinin karaciğerdeki etkisini araştırmak için sıklıkla kullanılan ve hepatositlere benzer özellikleri nedeniyle karaciğer protein sentezinin değerlendirilmesinde kullanılabileceği bildirilen HepG2 hücreleri kullanıldı $(9,11)$. Çalışmamızda, $0.5 \mathrm{mM}$ ve $1 \mathrm{mM}$ aspirin uygulanan HepG2 hücrelerinde hücre canlılığı azdı. Sonuçlarımızla benzer şekilde Miao ve ark. (19) $1 \mathrm{mM}$ aspirinin hücre canlılığını azalttığını bildirilmişlerdir. 48 saat sonunda aspirin uygulamasına bağlı olarak görülen bu hücre sayısındaki azalma aspirinin HepG2 hücrelerinde proliferasyonunu inhibe etmesinden dolayı olabilir çünkü Liu ve ark. (20), aspirinin HepG2 hücrelerinin proliferasyonunu glukoz metabolizması aracılığıyla inhibe ettiğini bildirmişlerdir. 
Çalışmamızda

uygulanan

aspirin

konsantrasyonlarının PON1 protein düzeylerini anlamlı olarak değiştirmediğini ve esas olarak PON1 enzimine ait olan arilesteraz aktivitesini arttırdığını bulduk. Çalışmamızla uyumlu olarak, Jaichander ve ark. (9), aspirinin HepG2 hücrelerinde arilesteraz aktivitesini arttırdığını bildirmişlerdir. Çalışmamızdaki PON1 protein düzeylerinde anlamlı bir değişiklik olmamasına rağmen arilesteraz aktivitesinin artması, aspirinin PON1 enziminin substratı olmasından kaynaklanabilir $(10,11)$ ve artan substrat konsantrasyonu enzim aktivitesinde artışa yol açmış olabilir. Ayrıca Kamble ve ark. (21), PON1 enziminin aspirinin hidrolizinde görev almasının yanında oluşan salisilik asitin metabolizması sonucu oluşan hidrojen peroksit ve süperoksitin HepG2 hücrelerinde katalaz, süperoksit dismutaz ve hem oksijenaz gibi major antioksidan enzimler ile birlikte PON1 enzimini de uyardığını bildirmişlerdir. Ayrıca Aviram ve ark. (22), PON1 enziminin peroksidaz benzeri aktivite ile lipoprotein peroksitleri, kolesteril linoleat hidroperoksitleri ve aynı zamanda direkt olarak hidrojen peroksiti de hidroliz etme kapasitesinin olduğunu göstermişlerdir. Bu sebeplerle aspirinle birlikte metabolizması sonucu oluşan moleküllerin de PON1 enziminin substratı olması da arilesteraz aktivitesindeki bu artışa yol açmış olabilir.

Literatürde, aspirinin PON1 protein düzeyine etkisini araştıran tek bir çalışmaya rastladık ve bu çalışmada Blatter-Garin ve ark. (13) koroner arter hastalığı olan ve aspirin kullanan bireylerde, kullanmayanlara göre serumda PON1 protein düzeylerinin ve aktivitelerinin daha yüksek olduğunu bildirmişlerdir. Çalışmamızdan farklı olarak Blatter-Garin ve ark. (13) bildirdiği serumdaki yüksek PON1 düzeylerinden aspirinin serumda PON1 yıkımını önlemesi sorumlu olabilir. Çünkü PON1 enzimi oksidatif strese karşı tampon görevi görür, oksidatif stresi ortadan kaldırmaya çalışırken yıkılarak miktarı azalır ve antioksidan özellikleri de olan aspirin bu yıkımı engellemiş olabilir $(5,23)$. Diğer taraftan literatürde aspirinin serumda PON enzim aktivitelerini değiştirmediğini de bildiren çalışmalar da bulunmakta olup aspirinin serumdaki PON1 protein düzeyine ve aktivitelerine etkisinin tam olarak aydınlatılması için yeni çalışmalara intiyaç vardır $(24,25)$.

PON2 neredeyse tüm dokularda sentezlenen hücre içi bir enzimdir ve PON1 ve PON3 enzimleri gibi antioksidan ve ateroskleroza karşı koruyucu bir enzimdir (3). Bu çalışma ile aspirinin PON2 enzimi üzerine etkisini ilk kez araştırdık. Çalışmamızda HepG2 hücrelerine uygulanan farklı aspirin konsantrasyonları PON2 düzeylerini değiştirmedi. $\mathrm{Bu}$ bulgumuz, kardiyovasküler hastalıkların önlenmesi ve tedavisinde kullanılan aspirinin PON2 enzimi üzerinden etkisinin olmayabileceğine işaret etmektedir.

$\mathrm{Bu}$ çalışma ile ilk kez aspirinin PON3 protein düzeylerini artırdığını HepG2 hücrelerinde gösterdik. Aspirinin PON3 protein düzeyini arttırması, bu molekülün kardiyovasküler sistem üzerine yeni olumlu etkilerinden biri olabilir, çünkü PON3 enzimi oksidatif stresi ve inflamasyonu önler ve ateroskleroza karşı savaşır (5). Ayrıca PON1 enzimi ile kıyaslandığında, tavşanlarda PON3 enziminin, PON1 enzimine göre dolaşımda daha az bulunmasına rağmen LDL oksidasyonunu önlemede daha etkili olduğu gösterilmiştir (26). Bununla birlikte PON3 enzimi çok az da olsa arilesteraz aktivitesi de göstermektedir ki (8), aspirinin arilesteraz aktivitesini arttırmasında PON3 enziminin de katkısı olabilir.

Çalışmamızda aspirinin PON3 protein düzeylerini arttırmasına rağmen PON1 ve PON2 protein düzeylerini değiştirmemesi özellikle PON3 enziminin PON1 ve PON2 enzimlerinden farklı düzenlendiğini göstermekte olup, önceki çalışmalarımızda $(6,7)$ bulduğumuz PON1 ve PON3 protein düzeylerinin farklı moleküller tarafından farklı değişimler göstermesini de destekler niteliktedir.

\section{Sonuç}

Çalışmamı aspirinin insan kaynaklı hepatoma hücrelerinde PON1 ve PON2 protein düzeylerini değiştirmediğini, PON3 protein düzeylerini ve arilesteraz aktivitesini arttırdığını gösterdi.

\section{Açıklamalar}

Bu çalışma herhangi bir kişi, kurum ya da kuruluş tarafından desteklenmemiştir ve yazarlar arasında çıkar çatışması yoktur. 


\section{Kaynaklar}

1. Gaglia MA Jr, Clavijo L. Cardiovascular pharmacology core reviews: aspirin. J Cardiovasc Pharmacol Ther 2013; 18 (6): 505-13.

2. Schrör K, Rauch BH. Aspirin and lipid mediators in the cardiovascular system. Prostaglandins Other Lipid Mediat 2015; 121 (Pt A): 17-23.

3. She ZG, Chen HZ, Yan Y, Li H, Liu DP. The human paraoxonase gene cluster as a target in the treatment of atherosclerosis. Antioxid Redox Signal 2012; 16 (6): 597-632.

4. Chistiakov DA, Melnichenko AA, Orekhov AN, et al. Paraoxonase and atherosclerosis-related cardiovascular diseases. Biochimie 2017; 132: 19-27.

5. Précourt LP, Amre D, Denis MC, et al. The three-gene paraoxonase family: physiologic roles, actions and regulation. Atherosclerosis 2011; 214 (1): 20-36.

6. Ozgun E, Ozgun GS, Tabakcıoğlu K, Gokmen SS, Sut N, Eskıocak S. Effect of lipoic acid on paraoxonase-1 and paraoxonase-3 protein levels, mRNA expression and arylesterase activity in liver hepatoma cells. Gen Physiol Biophys 2017; 36 (4): 465-70.

7. Sayilan Ozgun G, Ozgun E, Tabakcıoğlu K, Suer Gokmen S, Eskiocak S, Cakir E. Caffeine increases apolipoprotein A-1 and paraoxonase-1 but not paraoxonase-3 protein levels in human-derived liver (HepG2) cells. Balkan Med J 2017; 34 (6): 534-9.

8. Draganov DI, Teiber JF, Speelman A, Osawa Y, Sunahara R, La Du BN. Human paraoxonases (PON1, PON2, and PON3) are lactonases with overlapping and distinct substrate specificities. J Lipid Res 2005; 46 (6): 1239-47.

9. Jaichander P, Selvarajan K, Garelnabi M, Parthasarathy S. Induction of paraoxonase 1 and apolipoprotein AI gene expression by aspirin. J Lipid Res 2008; 49 (10): 2142-48.

10. Santanam N, Parthasarathy S. Aspirin is a substrate for paraoxonase-like activity: implications in atherosclerosis. Atherosclerosis 2007; 191 (2): 272-75.

11. Bahar FG, Imai T. Aspirin hydrolysis in human and experimental animal plasmas and the effect of metal cations on their hydrolase activities. Drug Metab Dispos 2013; 41 (7): 1450-6.

12. Bouma ME, Rogier E, Verthier N, Labarre C, Feldmann G. Further cellular investigation of the human hepatoblastoma-derived cell line HepG2: morphology and immunocytochemical studies of hepatic-secreted proteins. In Vitro Cell Dev Biol 1989; 25 (3 Pt 1): 267-75.

13. Blatter-Garin MC, Kalix B, De Pree S, James RW. Aspirin use is associated with higher serum concentrations of the anti-oxidant enzyme, paraoxonase-1. Diabetologia 2003; 46 (4): 594-5.

14. Borthwick GM, Johnson AS, Partington M, Burn J, Wilson R, Arthur HM. Therapeutic levels of aspirin and salicylate directly inhibit a model of angiogenesis through a Cox-independent mechanism. FASEB J 2006; 20 (12): 2009-16.

15. Ahmadian S, Barar J, Saei AA, Fakhree, MA Omidi Y. Cellular toxicity of nanogenomedicine in MCF-7 cell line: MTT assay. J Vis Exp 2009; 26: 1191.

16. Lowry OH, Rosebrough NJ, Farr AL, Randall RJ. Protein measurement with the Folin phenol reagent. J Biol Chem 1951;193: 265-75.

17. Schneider CA, Rasband WS, Eliceiri KW. NIH Image to ImageJ: 25 years of image analysis. Nat Methods 2012; 9 (7): 671-5.

18. Gan KN, Smolen A, Eckerson HW, La Du BN. Purification of human serum paraoxonase/arylesterase. Evidence for one esterase catalyzing both activities. Drug Metab Dispos 1991;19(1):100-06.

19. Miao R, Xu X, Wang Z, Liu S, Qu K, Chen W, Liu C. Synergistic effect of nutlin-3 combined with aspirin in hepatocellular carcinoma HepG2 cells through activation of Bcl-2/Bax signaling pathway. Mol Med Rep 2018; 17 (3): 3735-43.

20. Liu YX, Feng JY, Sun MM, et al. Aspirin inhibits the proliferation of hepatoma cells through controlling GLUT1mediated glucose metabolism. Acta Pharmacol Sin doi:10.1038/s41401-018-0014-x.

21. Kamble P, Selvarajan K, Aluganti Narasimhulu C, et al. Aspirin may promote mitochondrial biogenesis via the production of hydrogen peroxide and the induction of Sirtuin1/PGC-1 $\alpha$ genes. Eur J Pharmacol. 2013 Jan 15; 699 (1-3): 55-61. 
22. Aviram M, Rosenblat M, Bisgaier $C L$, et al. Paraoxonase inhibits high-density lipoprotein oxidation and preserves its functions. A possible peroxidative role for paraoxonase. J Clin Invest 1998;101(8):1581-90.

23. Shi X, Ding M, Dong Z, et al. Antioxidant properties of aspirin: characterization of the ability of aspirin to inhibit silica-induced lipid peroxidation, DNA damage, NF-kB activation, and TNF-a production. Mol Cell Biochem 1999; 199 (1-2): 93-102.

24. Ames PR, Batuca JR, Muncy IJ, et al. Aspirin insensitive thromboxane generation is associated with oxidative stress in type 2 diabetes mellitus. Thromb Res 2012; 130 (3): 350-4.

25. Kurban S, Mehmetoglu I. Effects of acetylsalicylic acid on serum paraoxonase activity, Ox-LDL, coenzyme Q10 and other oxidative stress markers in healthy volunteers. Clin Biochem. 2010; 43 (3): 287-90.

26. Draganov DI, Stetson PL, Watson CE, Billecke SS, La Du BN. Rabbit serum paraoxonase 3 (PON3) is a high density lipoprotein-associated lactonase and protects low density lipoprotein against oxidation. J Biol Chem 2000; 275 (43): 33435-42. 